\title{
Volatile aroma compounds in infusions of stems and rosette leaves of Sideritis raeseri Boiss. \& Heldr. from R. Macedonia, Albania and Greece
}

\author{
Bujar Qazimi*, Gjoshe Stefkov, Marija Karapandzova, Ivana Cvetkovikj, \\ Svetlana Kulevanova
}

Institute of Pharmacognosy, Faculty of Pharmacy, University SS Cyril and Methodius, Skopje, Republic of Macedonia

Received: April 2014; Accepted: June 2014

\begin{abstract}
The composition of the volatile aroma components was defined in the infusion prepared by stems of Sideritis raeseri (SR-S) from R. Macedonia, Albania and Greece and in the infusion of rosette leaves of S. raeseri (SR-R) from R. Macedonia. Analysis were made by gas chromatography (GC/FID/MS) equipped with a headspace (HS) sampler. Twenty components (12 monoterpenes representing 76.70$94.84 \%$ and 8 sesquiterpenes representing $5.16-18.55 \%$ of the entire volatiles) were identified as aroma components in SR-S samples. The predominant components in all samples were $\beta$-pinene, $\alpha$-pinene and trans-caryophyllene. The high abundance of limonene and $\delta$-3-carene were characteristic for the samples from Greece and 1,8-cineole was for the samples from R. Macedonia and Albania. In the infusions of SR-R, ten components were identified, 5 monoterpenes (73.20-83.89\%) and 5 sesquiterpenes (16.10-26.80\%). Prevailing components in all tested samples of SR-R were $\beta$-pinene, $\alpha$-pinene, 1,8-cineole and $\alpha$-epi-murolol. There was almost no difference in the chemical profiles of the aroma compounds between SR-S and SR-R. Infusion of rosette leaves exhibit very similar aroma compounds profile with the infusion of stems of $S$. raeseri.
\end{abstract}

Keywords: Sideritis raeseri, infusion, volatile aroma components, Headspace, GC/MS.

\section{Introduction}

Sideritis raeseri Boiss. \& Heldr. is endemic to the Balkan Peninsula and is reported to grow in Greece, R. Macedonia and Albania. Mountain tea is a traditional beverage in the Balkan countries, prepared as a refreshing herbal tea. Aerial parts of this plant are widely utilized in Mediterranean folk medicine in the form of a decoction or infusion. This herb is often used to treat the common cold, to alleviate sinus congestion, pains and virus infections, including influenza (Heywood, 1972; Obon de Castro, 1994; Gabri-

\footnotetext{
*bqazimi2003@yahoo.com
}

eli et al., 2005; Bojović et al., 2011). Rosette leaves traditionally is not used.

Various extracts and essential oils of $S$. raeseri have shown different types of activities as: antioxidant (Gabrieli et al., 2005; Koleva et al., 2003; Pljevljakusić et al., 2011; Karapandzova et al., 2013; Petreska et al., 2011b), antibacterial (Kostadinova et al., 2008; Menković et al., 2010), spasmolytic (Branković et al., 2011), hypotensive, vasorelaxant and cardiodepressant (Kitić et al., 2012). These activities are due to the presence of flavonoids, phenolic acids, terpenes, iridoids, coumarins, lignans, sterols, phenylpropanoids (Kostadinova et al., 2008; Pljevljakusić et al., 2011; Karapandzova et al., 2013; Janeska et al., 2007; Qazimi et al., 2010; Fraga B.M., 2012; Petreska et al., 2011a; 
Petreska et al., 2011b; Alipieva et al., 2010), and a complex mineral composition (Pljevljakusić et al., 2011; Spaseska et al., 2011; Karapandzova et al., 2013).

However, the specific and particular aroma is maybe the most important reason for the wide use of the tea by the Balkan peoples. Although numerous data have been published about the chemical composition of the essential oils (Kostadinova et al., 2008; Pljevljakusić et al., 2011; Petreska et al., 2011b; Menković et al., 2013; Tzakou, 2002; Galati et al., 1996) and aroma components in the fresh and dried aerial parts of $S$. raeseri (Qazimi et al., 2014), there are no data about the volatile aroma compounds in the infusion of $S$. raeseri. To analyze these compounds a refined method of headspace sampling hyphenated with GC/FID/ MS analysis can be utilized (Watson, 2005).

Taking into account all the considerations mentioned above, the aim of this work was the determination of the volatile aroma compounds in the infusion of dried stems and infusion of rosette leaves of mountain tea ( $S$. raeseri) using a headspace (HS) method with GC/FID/MS.

\section{Material and methods}

\section{Plant material}

The aerial parts (stems) (SR-S) of the flowering plants (20-25 cm from the top) of $S$. raeseri were collected in different localities in National Park Galichica (R. Macedonia), Albania and Greece and rosette leaves (SR-R) of S. raeseri were collected in different localities in National Park Galichica (R. Macedonia) during the summer of 2012 (Table 1). The plant material was air dried, packed in paper bags and kept in a dark and cold place until analysis. Plant identity was verified and voucher specimens were deposited at the Institute of Pharmacognosy, Faculty of Pharmacy, Skopje, R. Macedonia.

\section{Preparation of the infusion}

Infusions were made from $1 \mathrm{~g}$ plant material covered with $100 \mathrm{ml}$ boiling water and left for 5 minutes in a closed vessel, stirring and filtered.

\section{$G C$ and $G C-M S$ analyses}

$5 \mathrm{ml}$ of infusion of the stems or infusion of the rosette leaves was put in sealed vials, warmth for 5 minutes and the gas phase (highly volatile compounds) was investigated on Agilent 7890A Gas Chromatography system equipped with flame ionization detector (FID) and Agilent 5975C Mass Quadrupole detector as well as capillary flow technology which enable simultaneous analysis of the sample on both detectors. HP-5ms (30 m x $0.25 \mathrm{~mm}$, film thickness $0.25 \mu \mathrm{m}$ ) capillary column was used. Operating conditions were as follows: oven temperature $60{ }^{\circ} \mathrm{C}, 20$ ${ }^{\circ} \mathrm{C} / \mathrm{min}$ to $280{ }^{\circ} \mathrm{C}$; helium as carrier gas at a flow rate of $1 \mathrm{~mL} / \mathrm{min}$; injector temperature $260^{\circ} \mathrm{C}$ and FID temperature $270{ }^{\circ} \mathrm{C} .1000 \mu \mathrm{L}$ of gas phase was injected at split ratio $1: 1$. The mass spectrometry conditions were: ionization voltage $70 \mathrm{eV}$, ion source temperature $230^{\circ} \mathrm{C}$, transfer line temperature $280{ }^{\circ} \mathrm{C}$ and mass range from 50-500 Da. The MS was operated in scan mode.

\section{Head Space method}

Incubation temperature was $80{ }^{\circ} \mathrm{C}$, incubation time 5 min, syringe temperature $85^{\circ} \mathrm{C}$ and agitator speed $500 \mathrm{rpm}$.

\section{Identification and quantification of the components}

Identification of the components was made by comparing mass spectra of components with those from Nist, Wiley and Adams mass spectra libraries, by AMDIS (Automated Mass Spectral Deconvolution and Identification

Table 1. Specimens of $S$. raeseri

\begin{tabular}{llcl}
\hline \multicolumn{1}{c}{ Species } & \multicolumn{1}{c}{ Locality } & $\begin{array}{c}\text { Voucher } \\
\text { specimen }\end{array}$ & Symbol \\
\hline \multirow{5}{*}{ S. raeseri-stems } & R.M., Galichica, Baba & S1/12 & SR-S (1) \\
& R.M., Galichica, Kazani & S2/12 & SR-S (2) \\
& R.M., Galichica, Korito & S3/12 & SR-S (3) \\
& R.G., Lefkada & S4/12 & SR-S (4) \\
& R.A., Tepelena & S5/12 & SR-S (5) \\
& R.A., Gramoz & S6/12 & SR-S (6) \\
& R.G., Parga & S7/12 & SR-S (7) \\
leaves & R.M., Galichica, Baba & S1/R-12 & SR-R (1) \\
& R.M., Galichica, Kazani & S2/R-12 & SR-R (2) \\
& R.M., Galichica, Korito & S3/R-12 & SR-R (3) \\
\hline
\end{tabular}

R.M. - R. Macedonia, R.G. - R. Greece, R.A. - R. Albania 
System) and by comparing literature and estimated Kovat's (retention) indices that were determined using mixture of homologous series of normal alkanes from $\mathrm{C}_{9}$ to $\mathrm{C}_{25}$ in hexane, under the same above mentioned conditions.

The percentage ratio of the components was computed by the normalization method of the GC/FID peak areas and average values were taken into further consideration.

\section{Results and discussion}

The chemical composition of aroma compounds in the infusion of stems of $S$. raeseri $(S R-S)$

Total of 20 individual components were identified in the infusion of stems of $S$. raeseri (SR-S), collected from three different localities in R. Macedonia, two localities in Albania and two localities in Greece, representing $92.25-100 \%$ of the total content (Table 2). Data analysis of the chemical composition revealed four different classes of components: monoterpene hydrocarbons $(\mathrm{MH})$
58.32-94.84\%, oxygen containing monoterpenes (OM) up to $29.93 \%$, sesquiterpene hydrocarbons ( $\mathrm{SH}) 3.66-15.55 \%$ and oxygen containing sesquiterpenes (OS) up to $8.17 \%$ (Fig. 1).

The most abundant components in all SR-S samples were monoterpenes $\beta$-pinene (26.83-63.13\%) and $\alpha$-pinene (16.82-28.16\%), followed by sesquiterpenes trans-caryophyllene (2.36-7.07\%), $\alpha$-copaene (1.08-4.95\%) and $\alpha$-epimurolol (1.14-4.88\%). It is important to stress the presence of 1,8 -cineole $(3.49-9.35 \%)$, found only in the samples from R. Macedonia and Albania. The higher abundance of limonene and $\delta$-3-carene $(3.67-18.7 \%$ and $1.06-10.63 \%$, respectively) were specific for the samples from Greece.

The chemical composition of aroma compounds in the infusion of rosette leaves of $S$. raeseri $(S R-R)$ :

Total of 10 individual components were identified in the infusion of rosette leaves samples of $S$. raeseri (SR$\mathrm{R})$, collected from three different localities in R. Macedo-

Table 2. Chemical composition of volatile aroma compounds in the infusion of stems of S. raeseri (SR-S) (\%)

\begin{tabular}{|c|c|c|c|c|c|c|c|c|c|c|}
\hline \multirow{2}{*}{ No. } & \multirow{2}{*}{ Components } & \multirow{2}{*}{ KIL } & \multirow{2}{*}{ KIE } & \multicolumn{7}{|c|}{ SR-S } \\
\hline & & & & $(1)$ & $(2)$ & (3) & (4) & (5) & (6) & (7) \\
\hline 1 & $\alpha$-Thujene & 924 & 933.7 & - & - & - & 2.41 & - & - & - \\
\hline 2 & $\alpha$-Pinene & 932 & 937.5 & 16.82 & 22.66 & 23.43 & 18.13 & 28.16 & 26.15 & 26.98 \\
\hline 3 & Sabinene & 969 & 966.4 & - & - & 3.30 & - & - & - & - \\
\hline 4 & $\beta$-Pinene & 974 & 973.8 & 41.50 & 58.74 & 48.13 & 26.83 & 62.73 & 60.14 & 63.13 \\
\hline 5 & $\delta$-3-Carene & 1008 & 989.7 & - & - & 1.27 & 10.63 & - & - & 1.06 \\
\hline 6 & Limonene & 1024 & 1005.9 & - & - & - & 18.70 & - & - & 3.67 \\
\hline 7 & 1,8-Cineole & 1033 & 1017.2 & 5.49 & 9.55 & 6.26 & - & 3.49 & 3.84 & - \\
\hline 8 & $\alpha$-Campholenal & 1122 & 1102.0 & 2.89 & - & - & - & - & - & - \\
\hline 9 & trans-Pinocarveol & 1135 & 1118.0 & 7.15 & - & - & - & - & 1.24 & - \\
\hline 10 & Pinocarvone & 1160 & 1159.3 & 5.37 & - & - & - & - & 1.54 & - \\
\hline 11 & Myrtenal & 1195 & 1195.2 & 6.25 & - & - & - & - & 1.08 & - \\
\hline 12 & Bornyl acetate & 1284 & 1260.9 & 2.78 & - & 1.93 & - & - & - & - \\
\hline 13 & $\alpha$-Copaene & 1374 & 1345.9 & 4.75 & 4.95 & 3.24 & 4.46 & - & 1.08 & 2.80 \\
\hline 14 & trans-Caryophyllene & 1417 & 1387.3 & - & - & 2.55 & 7.07 & 4.20 & 2.58 & 2.36 \\
\hline 15 & Bicyclogermacrene & 1500 & 1501.7 & - & - & - & 4.02 & - & - & - \\
\hline 16 & $\alpha$ - Muurolene & 1500 & 1468.0 & - & - & 1.72 & - & - & - & - \\
\hline 17 & Caryophyllene oxide & 1582 & 1552.6 & - & - & 1.61 & 3.00 & - & 1.21 & - \\
\hline 18 & Globulol & 1590 & - & 2.12 & - & 2.18 & - & - & - & - \\
\hline 19 & $\alpha$-epi-Murolol & 1640 & 1613.4 & 4.88 & 4.1 & 4.38 & - & - & 1.14 & - \\
\hline \multirow[t]{2}{*}{20} & Valeranone & 1674 & - & - & - & - & - & 1.42 & - & - \\
\hline & Total $(\%)$ & & & 100 & 100 & 100 & 95.25 & 100 & 100 & 100 \\
\hline
\end{tabular}

SR-S (1)-(7) = infusions of stems of S. raeseri from Galichica, Baba, R.M., Galichica, Kazani, R.M., Galichica, Korito, R.G., Lefkada, R.A., Tepelena, R.A., Gramoz, R.G., Parga, respectively), (-)- not found; KIL- Kovats (retention) index- literature data (Adams, 2007), KIE - Kovat's (retention) index experimentally determined (AMDIS). 


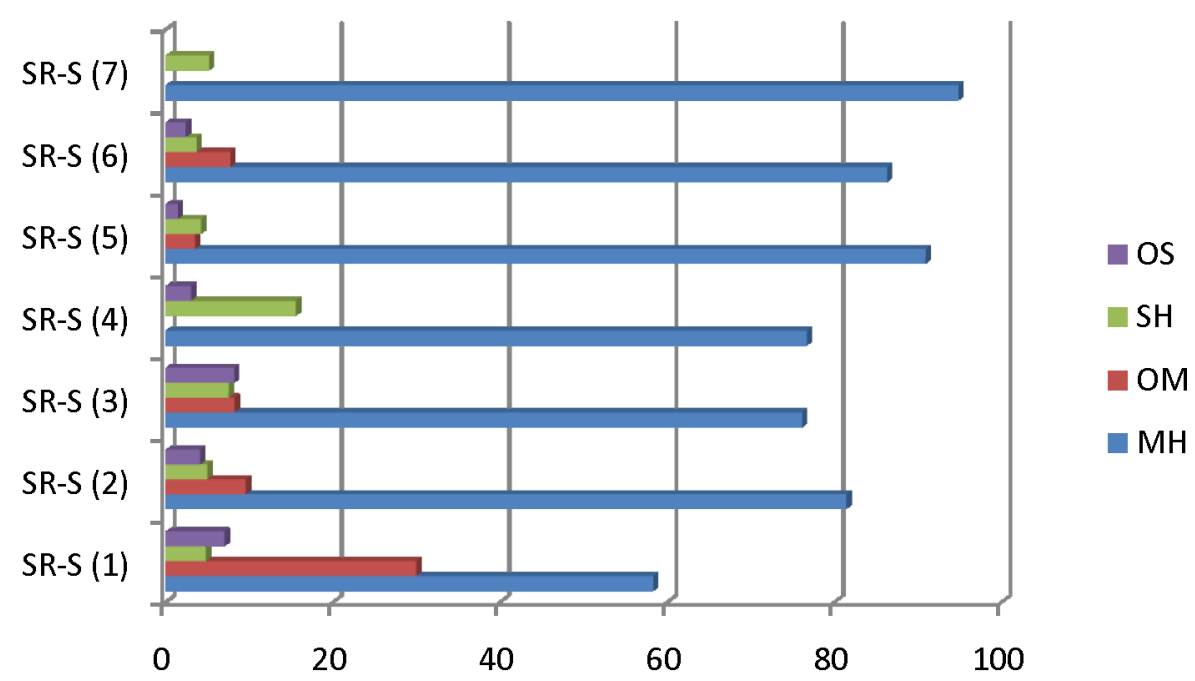

Fig.1. The content of different classes of volatile aroma components in the infusion of stems of S. raeseri: MH-monoterpene hydrocarbons, OM-oxygen containing monoterpenes, SH-sesquiterpene hydrocarbons, OS-oxygen containing sesquiterpenes.

Table 3. Chemical composition of volatile aroma compounds in the infusion of rosette leaves of S. raeseri (SR-R) (\%)

\begin{tabular}{rlccccc}
\hline \hline \multirow{2}{*}{ No. } & Components & KIL & KIE & \multicolumn{3}{c}{ SR-R } \\
\hline 1 & $\alpha$-Pinene & 932 & 937.5 & 18.11 & 17.34 & 19.75 \\
2 & Sabinene & 969 & 966.4 & 5.78 & 4.48 & - \\
3 & $\beta$-Pinene & 974 & 973.8 & 40.85 & 47.82 & 53.43 \\
4 & 1,8-Cineole & 1033 & - & 8.46 & 10.90 & 9.91 \\
5 & Bornyl acetate & 1284 & 1260.9 & - & 3.35 & - \\
6 & $\alpha$-Copaene & 1374 & 1345.9 & 6.26 & 2.95 & - \\
7 & Globulol & 1590 & - & 6.92 & - & - \\
8 & $\alpha$-epi-Murrolol & 1640 & 1613.4 & 13.62 & - & 16.91 \\
9 & $\alpha$-Cadinol & 1652 & 1621.8 & - & 7.91 & - \\
10 & Valeranone & 1674 & - & - & 5.24 & - \\
& Total (\%) & & & 100 & 99.99 & 100 \\
\hline
\end{tabular}

SR-R (1)-(3) = infusions of rosette leaves of S. raeseri from R.M., Galichica, Baba, R.M., Galichica, Kazani and R.M., Galichica, Korito, respectively; (-)- not found; KIL- Kovats (retention) index- literature data (Adams, 2007), KIE - Kovat's (retention) index experimentally determined (AMDIS).

nia, representing $99.99-100 \%$ of the total content (Table 3). Data analysis of the chemical composition revealed four different classes of components: $\mathrm{MH}(64.74-73.18 \%), \mathrm{OM}$ (8.46-14.25\%), SH (2.95-6.26\%) and OS (13.15-20.54\%) (Fig. 2).

The prevailing components in all SR-R samples were monoterpenes $\beta$-pinene (40.85-53.43\%), $\alpha$-pinene (17.34$19.75 \%)$ and 1,8-cineole $(8.46-10.90 \%)$, followed by sesquiterpene $\alpha$-epi-murolol (13.62-16.91\%).
The number of components found in SR-S was larger than in SR-R. Also, the share of the classes of components in $\mathrm{SR}-\mathrm{S}(\mathrm{MH}>\mathrm{OM}>\mathrm{SH}>\mathrm{OS})$ differed from $\mathrm{SR}-\mathrm{R}$ $(\mathrm{MH}>\mathrm{OS}>\mathrm{OM}>\mathrm{SH})$. Infusion of rosette leaves exhibit only smaller differences of aroma compounds profile with the infusion of stems of $S$. raeseri. The Fig. 3 shows the ratio between 5 major aroma volatile components in infusions of stems and rosette leaves, where small variations observed in the content of the dominant components. 


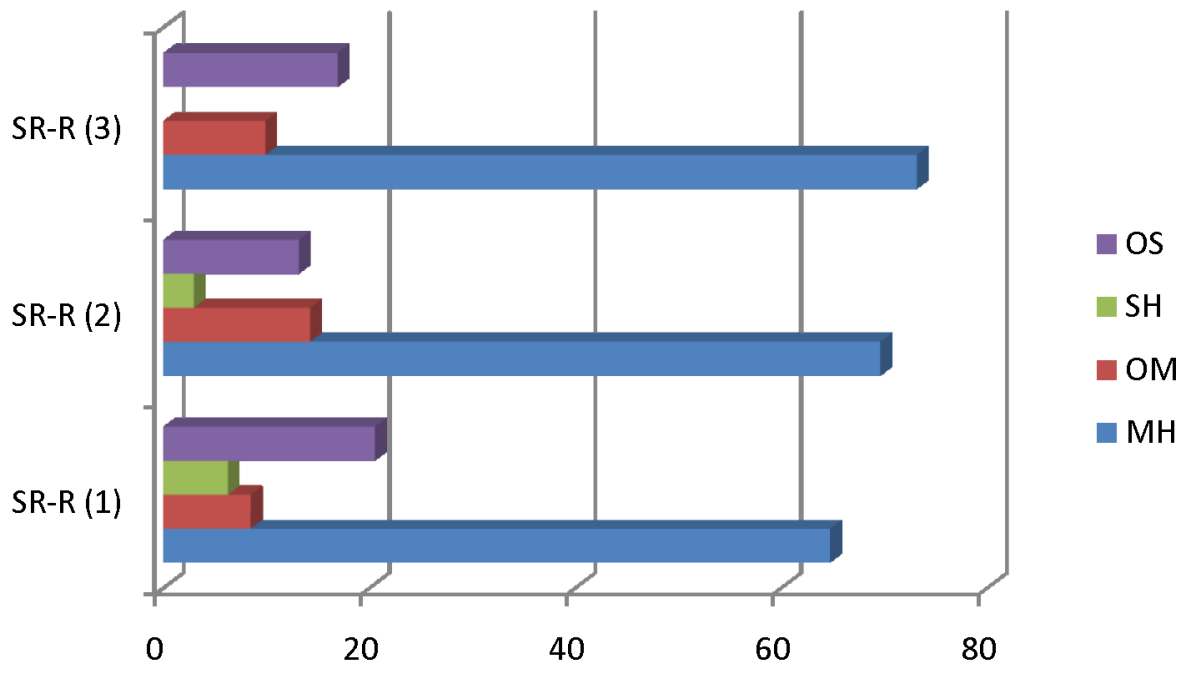

Fig.2. The content of different classes of volatile aroma components in the infusion of rosette leaves of S. raeseri: MHmonoterpene hydrocarbons, OM-oxygen containing monoterpenes, SH-sesquiterpene hydrocarbons, OS-oxygen containing sesquiterpenes.

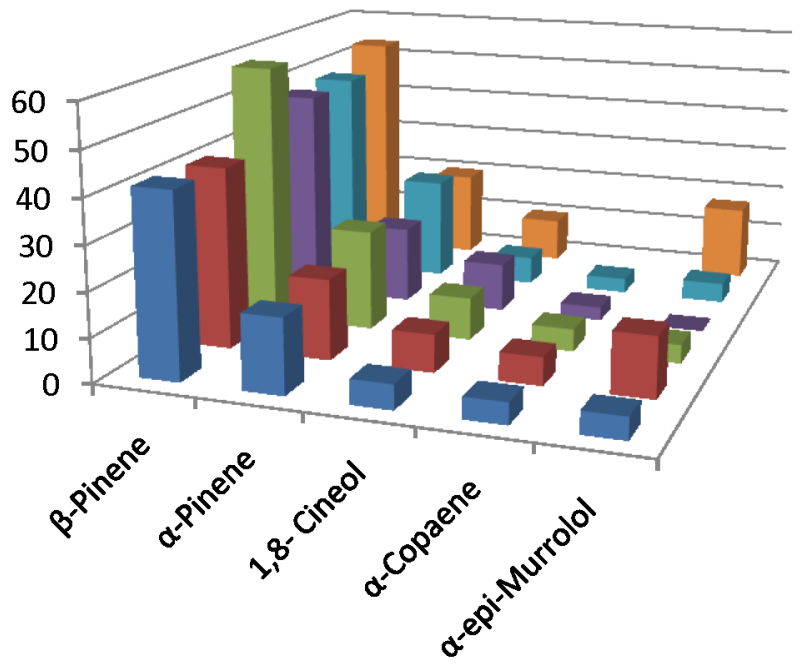

aSR-S (1)

$\square S R-R(1)$

- SR-S (2)

a SR-R (2)

SR-S (3)

a SR-R (3)

Fig.3. Main volatile aroma compounds in the infusion of stems (SR-S) and rosette leaves (SR-R) of S. raeseri ((1)-(3) samples collected from National park Galichica, R.M, from localities Baba, Kazani and Korito, respectively).

As there are no data for the volatile aroma compounds in the infusion of stems and rosette leaves of $S$. raeseri analyzed by HS-GC/FID/MS, most of our findings were compared with the aroma compounds in the fresh and dried stems of $S$. raeseri and essential oil composition. Similar results were obtained in our previous work where we analyzed the aroma compounds in the dried aerial parts of $S$. raeseri from R. Macedonia, Albania and Greece, and in the fresh aerial parts of $S$. raeseri from R. Macedonia, by HS-
GC/MS-FID. The monoterpene hydrocarbons $\beta$-pinene (21.9-48.8\% and 37.9-40.7\%), $\alpha$-pinene $(17.5-41.0 \%$ and $21.5-29.1 \%$ ), and limonene (1.2-15.7\% and 5.1-7.1\%), followed by the sesquiterpene hydrocarbons $\alpha$-copaene $(0.9$ $9.8 \%$ and $3.7-8.2 \%)$ and trans-caryophyllene (1.9-6.5\% and $1.4-4.5 \%$, respectively) were the major identified components (Qazimi et al., 2014). These components were identified as major components in the infusions of stems and rosette leaves as well. The infusions were also charac- 
terized with high presence of 1,8-cineole.

Pljevljakusic et al. analyzed the chemical composition of the essential oils from cultivated S. raeseri aerial parts at four different developmental phases using GC-MS and revealed that the sesquiterpene fraction was the predominant terpenoid group in all samples (58.2-67.8\%). The sesquiterpene hydrocarbon bicyclogermacrene was the main constituent of all analyzed oils (35.8-42.5\%), followed by spathulenon and $\beta$-caryophyllene (5.0-15.0\% and 0.1 $9.0 \%$, respectively); the major monoterpene hydrocarbon was cis- $\beta$-ocimene (3.0-4.9\%) (Pljevljakusic et al, 2011). Compared to these data, in the HS profile of our samples, bicyclogermacrene exceeded only in the sample SR-S (8) from Lefkada, Greece (4\%).

Kostadinova et al. reported the sesquiterpenes germacron and elemol acetate $(25.0$ and $15.9 \%$, respectively) as dominant components of the essential oil of $S$. raeseri from Galichica Mtn. (Kostadinova et al., 2008). These compounds were not identified in our tested samples.

\section{Conclussion}

Specific and particular aroma of $S$. raeseri is one of the reasons for the wide use by the Balkan's people. The chemical composition of the volatile aroma components was defined in the infusion prepared by stems of $S$. raeseri (SR-S) from R. Macedonia, Albania and Greece and in the infusion of rosette leaves of $S$. raeseri (SR-R) from $\mathrm{R}$. Macedonia. Analysis were made by gas chromatography (GC/FID/MS) equipped with a headspace (HS) sampler. In SR-S and SR-R samples were identified 20 and 10 components, respectively. The components belonged to several classes of components such as monoterpene hydrocarbons, oxygen containing monoterpenes, sesquiterpene hydrocarbons and oxygen containing sesquiterpenes. Infusion of the rosette leaves exhibit very similar aroma compounds profile with the infusion of the stems, comprising $\beta$-pinene, $\alpha$-pinene, 1,8-cineole, $\alpha$-copaene and $\alpha$-epi-murolol as predominate components and accordingly can be consider as a additional plant material source of this endemic aromatic plant. For complete assessment additional phytochemical analysis are require.

\section{References}

Adams, R., 2007. Identification of Essential Oil Components by Gas Chromatography/Mass Spectrometry, $4^{\text {th }}$ Ed. Allured Publishing Corporation, IL, USA, 9-31.

Alipieva, K., Petreska, J., Gil-izquierdo, A., Stefova, M., Evstatieva, L., Bankova, V., 2010. Influence of the extraction method on the yield of flavonoids and phenolics from Sideritis spp. (Pirin Mountain tea), Nat. Prod. Comm. 5, 51-54.

Bojović, D., Janković, S., Potpara, Z., Tadić, V., 2011. Summary of the phytochemical research perfomed to date on Sideritis species, Serb. J. Exp. Clin. Res. 12, 109-122.

Brankovic, S., Kitic, D., Radenkovic, M., Veljkovic, S., Jankovic,
T., Savikin, K., Zdunic, G., 2011. Spasmolytic activity of the ethanol extract of Sideritis raeseri spp. raeseri Boiss. \& Heldr. on the isolated rat ileum contractions, J. Med. Food $14,495-498$.

Fraga, B.M., 2012. Phytochemistry and chemotaxonomy of Sideritis species from the Mediterranean region, Phytochemistry 76, 7-24.

Galati, E.M., Germano, M.P., Rossitto A., Tzakou, O., Skaltsa, H., Roussis, V., 1996. Essential oil of Sideritis raeseri Boiss. et Heldr. ssp. raeseri, J. Essent. Oil Res. 8, 303-304.

Gabrieli, C.N., Kefalas, P.O., Kokkalou, E.L., 2005. Antioxidant activity of flavonoids from Sideritis raeseri, J. Ethnopharmacol. 96, 423-428.

Heywood, V., 1972. Genus Sideritis L. In Flora Europaea, Tutin, T., Heywood, V., Burges, N., Moore, D., Valentine, S., Walters, S., Webb, D., (Eds), Cambridge University Press, Cambridge, UK. 3, 138.

Janeska, B., Stefova, M., Alipieva, K., 2007. Assay of flavonoid aglycones from the species of genus Sideritis (Lamiaceae) from Macedonia whith HPLC-UV DAD, Acta Pharm. 57, 371-377.

Karapandzova, M., Qazimi, B., Stefkov, G., Bačeva, K., Stafilov, T., Kadifkova Panovska, T., Kulevanova, S., 2013. Chemical characterization, mineral content and radical scavenging activity of Sideritis scardica and $S$. raeseri from R. Macedonia and R. Albania, Nat. Prod. Comm. 8, 639-644.

Kostadinova, E., Alipieva, K., Stefova, M., Antonova, D., Evstatieva, L., Stefkov, Gj., Tsvetkova, I., Naydenski, H., Bankova, V., 2008. Influence of cultivation on the chemical composition and antimicrobial activity of Sideritis spp., Pharma. Mag. 4, 102-106.

Koleva, I., Linssen, J.P.H., van Beek, T.A., Evstatieva, L.N., Kortenska, V., Hadjieva, N., 2003. Antioxidant activity screening of extracts from Sideritis species (Labiatae) grown in Bulgaria, J. Sci. Food Agr. 83, 809-819.

Kitić, D., Brankovic, S., Radenkovic, M., Savikin, K., Zdunic, G., Kocic, B., Velickovic-Radovanovic, R., 2012. Hypotensive, vasorelaxant and cardiodepressant activities of the ethanol extract of Sideritis raeseri spp. raeseri Boiss. \& Heldr., J. Phys. Pharmacol. 63, 531 -535.

Menković , N., Goðevac, D., Milosavljević, S., Zdunić, G., Šavikin, K., Karadžić, I., 2010. Chemical composition and antimicrobial activity of Sideritis raeseri subsp. raeseri Heldr. et Boiss. polar extracts, Planta Med. 76, LS6.

Menković, N., Gođevac, D., Šavikin, K., Zdunić, G., Milosavljević, S., Bojadži, B., Avramoski, O., 2013. Bioactive compounds of endemic species Sideritis raeseri subsp. raeseri grown in national park Galičica, Rec. Nat. Prod. 7, 161-168.

Obón de Castro, C., Rivera-Núñez, D., 1994. A taxonomic revision of the section Sideritis (genus Sideritis) (Labiatae), Cramer JED, Berlin-Stuttgart.

Petreska, J., Stefkov, G., Kulevanova, S., Alipieva, K., Bankova, V., Stefova, M., 2011a. Phenolic compounds of Mountain tea from Balkans: LC/DAD/ESI/MS ${ }^{\mathrm{n}}$ profile and contents, Nat. Prod. Comm. 6, 21-30.

Petreska, J., Stefova, M., Ferreres, F., Moreno, A.D., TomásBarberán, A.F., Stefkov, G., Kulevanova, S., Gil-Izquierdo, A., 2011b. Dietary burden of phenolics per serving of "Mountain tea" (Sideritis) from Macedonia and correlation to antioxidant activity, Nat. Prod. Comm. 6, 1305-1314.

Pljevljakusic, D., Savikin, K., Jankovic, T., Zdunic, G., Ristic, M., Godjevac, D., Konic-Ristic, A., 2011. Chemical properties of the cultivated Sideritis raeseri Boiss. \& Heldr. subsp. raeseri, Food Chem. 124, 226-233. 
Spaseska, M., Karapandzova, M., Qazimi, B., Stefkov, Gj., Baceva, K., Stafilov, T., Kulevanova, S., 2011. The Content of Minerals in Herbs and Tea Infusions of Mountain Tea (Sideritis scardica and Sideritis raeseri), Maced. Pharm. Bull. 57:215-217.

Tzakou, O., 2002. The essential oil of Sideritis raeseri Boiss. et Heldr. ssp. attica (Heldr.) Pap. et Kok., J. Essent. Oil Res. 14, 376-377.

Qazimi, B., Karapandzova, M., Stefkov, G., Kulevanova, S., 2010. Chemical composition of ultrasonic-assisted n-hexane extracts of Sideritis scardica Griseb. and Sideritis raeseri Boiss. \& Heldr. (Lamiaceae) from Macedonia and Albania, Maced. Pharm. Bull. 56 (1,2), 45-56.

Qazimi, B., Stefkov, Gj., Karapandzova, M., Cvetkovikj, I., Kulevanova, S., 2014. Aroma compounds of Mountain Tea (Sideritis scardica and S. raeseri) from Western Balkan, Nat. Prod. Comm. Vol. 9 (9), 1369-1372.

Watson, G., 2005. Pharmaceutical Analysis, A textbook for Pharmacy Students and Pharmaceutical Chemists, Second Edition, Elsevier.

\title{
Испарливи арома компоненти во инфузи од цветни изданоци и розетни листови на Sideritis raeseri Boiss. \& Heldr. од Р. Македонија, Албанија и Грција
}

\author{
Бујар Ќазими, Ѓоше Стефков, Марија Карапанџова, Ивана Цветковиќ, \\ Светлана Кулеванова
}

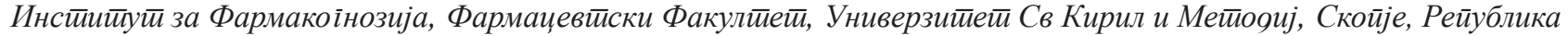
Макеоонија
\end{abstract}

Клучни зборови: Sideritis raeseri, инфуз, арома испарливи компоненти, хедспејс, GC/MS

Составот на испарливи арома компоненти е испитуван во инфузи подготвени од цветни изданоци на Sideritis raeseri (SR-S) од Р. Македонија, Албанија и Грција и во инфузи на розетни листови на S. raeseri (SR-R) од P. Македонија. Анализите се направени со помош на гасна хроматографија (GC/FID/MS) опремена со хедспејс (HS) семплер. Дваесет компонентите (12 монотерпени 76,70-94,84\% и 8 сесквитерпени 5,16-18,55\%) се идентификувани како арома компоненти во SR-S примероци. Доминантни компоненти во сите примероци беа $\beta$-pinene, $\alpha$-pinene и trans-кариофилен. Висока застапеност на лимонен и $\delta$-3-карен се карактеристични за примероците од Грција и 1,8-цинеол за примероците од P. Македонија и Албанија. Во инфузи на SR-R, идентификувани се десет компоненти, 5 монотерпени $(73,20-83,89 \%)$ и 5 сесквитерпени $(16,10-26,80 \%)$. Доминантни компоненти во сите испитувани примероци на SR-R ce $\beta$-pinene, $\alpha$-pinene, 1,8 -цинеол и $\alpha$-ері-муролол. Речиси не постои разлика на хемиските профили на арома компоненти меѓу SR-S и SR-R. Инфузи од розетни листови покажуваат многу слични профили на арома компоненти со инфузи од цветни изданоци на S. raeseri. 